Anderson Report ESO 2237

\title{
HAVE FARMERS LOST THEIR UNIQUENESS?
}

\author{
By
}

Renée Drury and Luther Tweeten ${ }^{*}$

"Research Assistant and Anderson Professor of Agricultural Marketing, Policy, and Trade, Department of Agricultural Economics, The Ohio State University, Columbus, OH. 


\section{Executive Summary}

Modern technology, communication, transportation, and economics transforming the farming industry in the last century also may have altered the character and personality of the typical farmer. Do farmers still personify the honest, hardworking, moral ideal or have they lost their uniqueness and become socially and politically indistinguishable from other members of society?

This study concludes that farmers have not lost their uniqueness. Results indicate that farmers differ from the general population in values such as morality, political ideology, work ethic, and outlook on life.

Data for the study are from the General Social Surveys of the National Opinion Research Center (NORC) at the University of Chicago. The average number of respondents is 1,505 per year for the period 1972 to 1993.

Results were compared for respondents divided into six groups: farm, rural, nonmetropolitan, suburb, medium size central city, and large central city. Farmers (owner operators, tenant operators, and farm managers) were defined by occupation; all other groups were classified by place of residence. Additional analyses focused on comparisons only between farmers and nonfarmers. Comparisons among groups were made for four basic domains: morality, political ideology, work ethic, and outlook on life.

In the category of morality, differences between nonfarmers and farmers are significant concerning religious service attendance, religious feelings, family structure, divorce rates, and satisfaction with friendships. Farmers ranked significantly higher than nonfarmers in measures of morality and all of these differences were stable through time; i.e., farmers have maintained their uniqueness.

Many differences between farmers and nonfarmers were found in political ideology, particularly concerning party affiliation and levels of government spending. All differences remained steady through time except party affiliation. Farmers are becoming more Democratic while nonfarmers are becoming more Republican. Because a greater proportion of farmers were initially Republican, these changes indicate converging political affiliations.
Many differences were found in outlook on life among the six reference groups, but none were found in the two-group analysis. Findings using the anomia scale include: Farmers (1) along with nonfarm rural people are less likely than others to agree that money is the most important thing in life next to health, (2) are least likely of all groups to believe you sometimes can't help wondering if anything is worthwhile anymore, (3) are less likely than any other group to believe that a person must live for today and let tomorrow take care of itself, (4) along with suburban people are less likely than other respondents to agree that the lot of the average man is getting worse, and (5) along with both suburban and medium-size city respondents are less likely than others to believe that a person doesn't really know whom he can count on.

For the remaining questions concerning outlook on life, farmers' opinions lie somewhere in the middle among the six respondent groups. Farmers are the least while nonfarm rural people are the most pessimistic, alienated, and fatalistic of all groups.

Despite their anomia, nonfarm rural people to our surprise indicate they are more happy than other groups. Farmers are very similar to nonmetropolitan and suburban people in this happiness domain, and these three groups rank only slightly lower than nonfarm rural people. Medium city and larger city residents rank lowest in happiness among all residence classes.

In summary, compared to the general population, the typical farmer has higher morals, is politically more conservative, and is happier and more satisfied with some aspects of life including work. Farmers have not lost their uniqueness. As a group, farmers are among the better-adjusted members of society. They are optimistic and have a healthy outlook on life both in terms of interpersonal relationships and general viewpoint.

We cannot necessarily conclude, however, that farmers rank above other groups in overall quality of life. Using the same data set as this study but correcting for income, age, and health, Blue and Tweeten (1994) found no statistically significant effect of residence on a farm or in a rural area on overall quality of life.

Favorable farm attitudes and morals are a 
positive force in American society. However, the relatively small and declining farm population means that farmers may less influence than be influenced by the large nonfarm population. Just how the different attitudes and morals of farmers found in this study effect society is a topic for further research. 


\title{
HAVE FARMERS LOST THEIR UNIQUENESS?
}

\author{
by \\ Renée Drury and Luther Tweeten
}

\section{Introduction}

A creed called farm fundamentalism, a set of beliefs that guide the way people think and act, dates at least back to the 19th century (Tweeten, 1989). Farm fundamentalism holds that all occupations depend on farming, agriculture must prosper if the nation is to prosper, and the family farm must be preserved. In addition, it holds that farmers are better citizens, have higher morals, and work harder than others. It holds that the nation will prosper if the work ethic and other farm values permeate the entire country. Therefore, it is said that farmers are uniquely worthy (Paarlberg, 1978).

Agriculture of today is very different from agriculture of the 19th century. Agriculture was more a way of life and less a business than it is today. Farm fundamentalism originated from a time when farming was the major source of the country's wealth, most people lived on small farms, and small family farms were efficient economic units. Driven by economies of scale and the need for more income to "keep up with the Joneses", farms have become larger and fewer. Most farm families have off-farm income. Industrialization has established better rural communication, transportation, and infrastructure tying society together. Farm people attend the same schools, shop in the same stores, and enjoy the same leisure activities as nonfarm people. Urban-based media now pervade all aspects of the American community, integrating rural people into the cultural fabric of the rest of the country. Economic integration is apparent from the fact that farm income per household equals that of nonfarmers after lagging for decades (U.S. Department of Agriculture, 1993).

Although modern technology, communication, transportation, and economics have transformed the farming industry in the last century, has this transformation altered the character and personality of the typical farmer? Does the farmer still personify the honest, hard-working, moral ideal or has he lost his uniqueness and become socially and politically indistinguishable from other members of society?

There is at least some evidence that farm families are of different psychological type than the general population. Jose and Crumly (1993), using the Myers-Briggs Type Indicator, found greater incidence of introverted, sensing types (as opposed to extroverted, intuitive types) in the farm population than in the general population. Farmers also were found to prefer judgment over perception in work and lifestyle to a greater extent than others. They conclude that these psychological preferences establish a trend for a structured, traditional society and also affect business and management decisions.

The objective of this study is to determine whether farmers differ from the general population in values such as morality, political ideology, work ethic, and outlook on life. The null hypothesis is that they do not differ significantly from other Americans in these aspects.

\section{Data and Methodology}

Data are from the General Social Surveys of the National Opinion Research Center (NORC) at the University of Chicago. They include 19 surveys administered during the years 1972 to 1993 and excluding 1979, 1981, and 1992. If the item was administered every year, there are 28,592 observations, 424 of which are farmers.

Respondents are divided into six groups (farm, rural, non-metropolitan, suburb, medium size central city, and large central city) for comparison with those indicating that they are farmers (owner operators, tenant operators, and farm managers) assigned to the first group. Spouses of farmers indicating an occupation other than farming are not classified as farmers. All other respondents are classified according to place of residence. Rural here excludes farmers and includes residents of an incorporated area of less than 2,500 residents, an unincorporated area of 1,000 to 2,499 , or open country within larger civil divisions. Nonmetropolitan is defined as either a county or small 
city of 10,000 to 49,999 residents or a town or village of 2,500 to 9,999 residents not part of a standard metropolitan area (SMA). Suburb is defined as any incorporated or unincorporated area of 1,000 or more residents within an SMA but not within a central city of the SMA. Respondents residing in an unincorporated area of a large central or medium central city are also included in this group. Medium city is defined as a central city of 50,000 to 250,000 people, and largecity as a central city of 250,000 or more people. Statistical tests are employed to detect significant differences among these six groups and also to detect differences between farmers and nonfarmers (five-group aggregate).

The questions selected for comparison among the six groups address four basic categories: morality, political ideology, work ethic, and outlook on life. Questions to assess morality include religious service attendance, religious feelings, divorce rates, satisfaction with family and friends, and arrest rates. Political ideology questions focus on party affiliation and attitudes toward government spending and intervention. To evaluate work ethic, we measure job satisfaction and the importance of certain factors for getting ahead in life. Outlook on life is addressed by questions concerning anomia as well as happiness in general. The anomia scale in the NORC surveys probes the respondent's world view and measures pessimism, meaninglessness (a perception that social and political events are overwhelmingly complex, without purpose, and lacking in predictability), and lack of trust (Seeman, 1991).

Farmers comprise approximately 1.5 percent of the total sample, and several of the sample items are not included every year. For many questions in the survey, the number of farmers is insufficient for analysis and the questions are omitted. for some questions we do include, the sample size is relatively small, so sampling error may be prominent. Sample size and statistical significance are shown with responses in the Annex to help the reader judge reliability of results. Responses of "don't know" or "no answer" were infrequent and we deleted them for this analysis. For each question, a chi-square test of independence using the 5 percent significance level assesses the extent to which the variables are related.

For the significant items in the two-group analysis, the trend toward convergence or divergence between nonfarmers and farmers through time is of particular interest. At issue is whether differences are getting smaller, larger or staying the same. To find out, for those items that ranged over at least three years, we ran regressions using the difference in response rate between nonfarmers and farmers as the dependent variable and the year as the independent variable. If the response can be yes or no, the dependent variable is simply the percentage of nonfarmers minus the percentage of farmers in the "yes" category (e.g., the difference in divorce rates between farmers and nonfarmers). For those items with multiple possible responses, the percentage in each response category is weighted using the indices assigned by NORC and averaged for both groups each year. The difference in this weighted average between nonfarmers and farmers serves as the dependent variable. If a significant time trend coefficient evidences convergence or divergence between farmers and nonfarmers, separate regressions are run using each group's average weighted response as the dependent variable to see whether it is nonfarmers or farmers who account for the shifting pattern through time. Table 1 shows overall results of all the tests. Other, more comprehensive tables are presented in the Annex in the order they are discussed in the paper. The results of the chisquare tests for differences between farmers and nonfarmers are given in footnotes following each table.

\section{Results}

\section{Morality}

We first assess morality as measured by religious service attendance, religious feeling, divorce and arrest rates, and relations with family and friends (see Annex Tables 1-8 for survey responses). For many people, religion provides the foundation for determining right and wrong. Insofar as this is true, religion may be considered a proxy for morality. Farmers and rural people attend religious services more often than the other groups, and, in addition, farmers indicate that they feel stronger in their religion than any of the other groups (see Annex Tables 1 and 2). Differences between farmers and nonfarmers concerning these two items are stable through time. 
Table 1. Summary of results.

\begin{tabular}{|c|c|c|}
\hline Category and Selected Components & \multicolumn{2}{|c|}{ Group Differences } \\
\hline & \multicolumn{2}{|c|}{ Number of significantly different items } \\
\hline & Between 6 groups & Between 2 groups \\
\hline Morality & 8 of 8 & 5 of 8 \\
\hline Religious service attendance & & no trend \\
\hline Strength in religion & & no trend \\
\hline $\begin{array}{l}\text { Family structure (both parents present, } \\
\text { one parent, or other relative) }\end{array}$ & & no trend \\
\hline Divorce rates & & no trend \\
\hline Satisfaction with friendships & & no trend \\
\hline Political ideology & 17 of 20 & 10 of 20 \\
\hline Political party affiliation & & convergence \\
\hline Spending for the environment & & no trend \\
\hline Spending for health & & no trend \\
\hline Assistance to big cities & & no trend \\
\hline Spending for law enforcement & & no trend \\
\hline Spending for drug rehabilitation & & no trend \\
\hline Spending for education & & no trend \\
\hline Assistance to blacks & & slight divergence \\
\hline Assistance to the poor & & no trend \\
\hline Work ethic & 9 of 16 & 3 of 16 \\
\hline Work satisfaction & & no trend \\
\hline Work if rich & & no trend \\
\hline Outlook on life & 10 of 10 & 0 of 10 \\
\hline
\end{tabular}


What the majority considers to be immoral is often made illegal. Thus another proxy for morality is arrest rates. The surveys ask whether respondents were ever picked up or charged by the police for any reason. The arrest rate of farmers (9.09 percent) was slightly above that of nonfarm rural (8.63 percent) and non-metropolitan (7.95 percent) respondents, but below that of suburb (11.44 percent), medium city (12.94 percent), and large city (14.19 percent) respondents.

Family disintegration is widely viewed as a source of social problems. At issue is whether the farm family is more cohesive than families in other places of residence. The sample indicates that farmers are more likely than others to have grown up in a home with their own mother and father present. This trend between farmers and nonfarmers is unchanging through time. People who grow up in a stable environment are likely to have the same experience in adulthood, and farmers, in fact, are less likely to have ever been divorced or legally separated. People in medium and large cities are the most likely to have grown up in single parent homes and they subsequently have had the highest divorce and separation rates. Statistical tests do not indicate that the gap between divorce rates of nonfarmers and farmers has narrowed significantly through time.

Compared to respondents from most other sectors, farmers are generally happier in their marriages and obtain greater satisfaction from family life and friendships, although the tests concerning marriage happiness and satisfaction from family life between farmers and nonfarmers are not significant. The main differences arise between residents of medium and large cities and the others. Nonetheless, these results are consistent with strong family values. Differences in satisfaction with friendships between farmers and nonfarmers have not changed through time.

Overall, farmers are significantly more religious, place greater value on family, and have relatively low arrest rates compared to other respondents. At least in these dimensions, the evidence is that farmers do indeed have higher morals. Nonfarm rural and non-metropolitan respondents ranked higher than medium city and large city respondents in most measures of morality.

\section{Political Ideology}

Political ideology is measured by political affiliation and priorities for government spending and interventions (Annex Tables 9, 10, and 11). Political party affiliation is divided into seven liberal-conservative gradients ranging from strong Democrat (assigned weight $=0$ ) to strong Republican (assigned weight $=6$ ) with Independent in the middle. A greater percentage of farmers than of others consider themselves to be either strong Republicans or not very strong Republicans. They are least likely among all groups to consider themselves Independent. Despite the relatively high percentage of farmers who consider themselves strong Republicans, they are exceeded only by those in large cities in the classification of strong Democrat. Thus, farmers are prominent at opposite poles of the political spectrum with relatively few identifying themselves as Independent and more identifying themselves as Republican than Democrat.

This political domain has changed significantly through time. Nonfarmers are becoming more Republican and farmers are becoming more Democratic. Because a higher proportion of farmers than nonfarmers were initially Republican, however, the trends are converging to similar party affiliations through time. That is, the political affiliations of farmers and nonfarmers are looking more alike.

The conservative viewpoint of many farmers is also reflected in their responses to the series of questions concerning government spending. Respondents are asked about spending levels on space exploration, the environment, health, law enforcement, drug rehabilitation, education, national defense, and assistance to big cities, blacks, the poor, and other countries. In all categories except national defense and assistance to other countries, a greater percentage of farmers than any of the other groups believe we are spending too much and a smaller percentage believe we are spending too little. A higher proportion of farmers than others deemed the nation is spending "too little" or "about right" on defense rather than "too much," an outcome consistent with farmers' conservative political philosophy. Farmers follow a pattern similar to other respondents - only a few say we are spending too little and a strong majority say we are spending too much on foreign assistance. The same results are obtained in the two-group analysis with the exception of government spending for space exploration. Differences between farmers and nonfarmers are stable through time for all items in this series, although the trend between farmers and 
nonfarmers concerning assistance to blacks is significant at about a 6 percent level. Individually, the trends are not significant, but there is a slight divergence over time.

Another series of questions assess attitudes towards government intervention in the economy. Options for improving the economy include control of wages by legislation, control of prices by legislation, cuts in government spending, government financing of projects to create new jobs, less government regulation of business, support for industry to develop new products and technology, support for declining industries to protect jobs, and a shorter work week to create more jobs.

Compared to other groups, farmers are more in favor of cuts in government spending and less government regulation of business, and less in favor of supporting declining industries to protect jobs. In the two-group analysis, only the last of these three items is significant at a 5 percent level. However, cutting government spending, control of prices, and reducing the work week are significant at about a 10 percent level. Overall, the findings are further evidence of farmers' more conservative beliefs. The six respondent groups do not differ significantly among themselves concerning control of prices, support for industry to develop new products and technology, and reducing the work week to create more jobs. The only area in which farmers appear different in attitude is control of wages by legislation. Paradoxically, farmers have the highest incidence of strongly favoring such control, although this item is not significant in the two-group analysis.

In summary, place of residence categorized by density of population in Annex Tables 9 to 11 trended to more liberal going from lowest population density (farm) to highest population density (large city). Residents of large cities were in most instances most liberal. For example, 72 percent of respondents from large cities compared to 60 percent of respondents from rural nonfarm areas and 33 percent of respondents from the farm say the nation is spending too little on the environment.

\section{Work Ethic}

Annex Tables 12 to 15 solicit respondents' attitudes toward work. Farmers are significantly more satisfied with their work than is any other group. The percentage indicating that they are very satisfied (59) is at least 10 percentage points greater than for others. No significant trend is apparent through time in the responses of farmers versus nonfarmers. In addition, 86 percent of farmers say that if they were to get enough money to live as comfortably as they would like for the rest of their lives, they would continue to work. This compares to 72 percent of the nonfarm rural, 71 percent of the non-metropolitan, 71 of the suburb, 73 percent of the medium size central city, and 71 percent of the large central city respondents. Both of these items are highly significant in the two-group analysis as well, and differences between farmers and nonfarmers are stable through time.

Respondents were asked to rate the importance of various attributes for getting ahead in life: coming from a wealthy family, having well educated parents, having a good education oneself, ambition, natural ability, hard work, knowing the right people, having political connections, a person's race, a person's religion, the part of the country one comes from, being born a man or a woman, and a person's political beliefs. Responses are divided into five scales including essential, very important, fairly important, not very important, and not important at all. The importance of coming from a wealthy family, hard work, knowing the right people, political connections, religion, and gender differ significantly in importance among groups.

Only 23 to 26 of the respondents to this series of questions are farmers, so sampling error may again be a problem. Farmers are the least likely of all groups to believe that coming from a wealthy family is important for getting ahead; 54 percent believe it is not very important or not important at all compared to 52 percent of the nonfarm rural, 44 percent of the non-metropolitan, 52 percent of the suburbs, 46 percent of the medium city, and 41 percent of the large city respondents. These differences are not significant in the two-group analysis however. Nonetheless, this may evidence a belief by farmers in the work ethic and that one can be successful without much outside assistance. Farmers' responses do not reflect the often decisive role of parents' wealth passed to their sons and daughters who are getting started in capital-intensive farming.

The farm work ethic is contradicted by another finding: Farmers and people in large cities were less likely than all other groups to believe that hard work is essential or very important for getting ahead in life. However, no farmers believe this item is not very important or not important at all, and the response item is not significant in the two- 
group analysis. In a related question concerning whether hard work or luck is most important for getting ahead, people in large cities and farmers more than other groups tended to believe that luck was more important than hard work, but this also is not significant in the two-group analysis. In general, farmers are not significantly different from others regarding beliefs about hard work.

In their response to the importance of knowing the right people to get ahead, farmers were concentrated at opposite poles with most of them thinking it is either essential or very important or not important at all. This is the only item of this response-set significant in the two-group analysis. The results may reflect sampling variation among the small number of farm respondents. Farming ordinarily is not considered an occupation that requires "knowing the right people" for success. However, many farm residents have off-farm jobs in service industries (as do city residents) where personal relationships are important. People in medium and large cities believe this variable is more important than do people in the other groups, including farmers, with slightly over half of them rating it as either essential or very important.

Along a similar line, farmers are more likely than most other groups to believe political connections are important for getting ahead, although 35 percent believe it is not important at all or not very important and 43 percent think it is only fairly important. When all nonfarm groups are averaged together the differences between groups are marginal, and this item is not significant in the two-group analysis.

More farmers think a person's religion is important in determining success in life compared to the other groups, although 52 percent say it is not very important or not important at all. This item is also not significant in the two-group analysis. Those who say it is important may conclude that God-fearing people achieve more in life because they receive divine favor or because following the 10 commandments is good business. Another interpretation is members of some religious groups are perceived to face discrimination or favor in jobs, lending, and other business activities.

Farmers also believe that gender is not crucial to getting ahead in life: 76 percent believe it is either not very important or not important at all. This compares to 63 percent of the nonfarm rural, 63 percent of the non-metropolitan residents, 61 percent of the suburban residents, 62 percent of medium-size city residents, and 54 percent of the large city residents. The difference between farmers and nonfarmers is not significant in the two-group analysis, however.

Results in Annex Table 15 are notable in showing similarities between farmers and largest city respondents in rating hard work relatively less important and luck relatively more important in getting ahead. Nonfarm rural, non-metropolitan, suburban, and medium city residents express a higher preference for hard work relative to luck for getting ahead. However, residents of all six sizes of place rated "hard work" over "luck"by at least a 4:1 margin. Thus, farmers as well as respondents from other sectors emphasize hard work as an important way to get ahead in life. The importance of work again indicates a commitment to the work ethic. The lesser importance of luck, politics, personal connections, and the like indicates a healthy lack of fatalism, pessimism, and alienation.

\section{Outlook on life}

All of the nine items about anomia (alienation, pessimism, fatalism) differ significantly among place of residence at the 5 percent level (Annex Table 16). However, none of the nine items is significant in the two-group analysis. These statements with which respondents can either agree or disagree are as follows: (1) Next to health, money is the most important thing in life. (2) You sometimes can't help wondering whether anything is worthwhile anymore. (3) To make money, there are no right and wrong ways anymore, only easy and hard ways. (4) Nowadays, a person has to live pretty much for today and let tomorrow take care of itself. (5) In spite of what some people say, the lot of the average man is getting worse, not better. (6) It's hardly fair to bring a child into the world with the way things look for the future. (7) Most public officials are not really interested in the problems of the average man. (8) These days a person doesn't really know whom he can count on. (9) Most people don't really care what happens to the next fellow.

Farmers along with nonfarm rural people are less likely than others to agree that money is the most important thing in life next to health. Thus rural people seem to be less motivated than others by money and materialistic concerns. This point is consistent with the farm fundamentalist creed discussed earlier.

Farmers are least likely of all groups to 
believe you sometimes can't help wondering if anything is worthwhile anymore. The difference between farmers and the weighted average of the other groups is about 5 percent. While this suggests farmers are less alienated than other groups, this difference is not significant in the two-group analysis.

Farmers are less likely than any other group to believe that a person must live for today and let tomorrow take care of itself. The difference between farmers and the weighted average of the other groups is about 5 percent, but the two-group difference is not significant. This result still may indicate less feeling of fatalism among farmers than among some other groups in society.

Statement (5), concerning the lot of the average man, measures pessimism. Farmers, along with suburban people, are less likely than other respondents to agree that the lot of the average man is getting worse.

Farmers, along with both suburban and medium-size city respondents, are less likely than others to believe that a person doesn't really know whom he can count on. This response item focuses on trust in interpersonal relationships, and results concur with those for the family life satisfaction and attributes for getting ahead discussed earlier.

For the remaining questions, farmers' opinions lie somewhere in the middle. Nonfarm rural people are the most likely group to agree with statements (2), (5), (6), (7), (8), and (9), and, along with non-metropolitan people, with (4). It appears that farmers are the least while nonfarm rural people are the most pessimistic, alienated, and fatalistic of all groups.

It is notable and puzzling that despite the finding of anomia, nonfarm rural people indicate they are the happiest among all groups (Annex Table 17). Farmers are very similar to nonmetropolitan and suburban people in this happiness domain, and these three groups rank only slightly lower than nonfarm rural people. Medium city and larger city residents rank lowest in happiness among all residence classes.

It is important to recognize that for all the significant differences in the six-group analysis mentioned above in the "outlook on life" category, most of the variation arises from differences among the nonfarm groups. In most cases, the opinions of farmers are closer to those of the suburban and medium-size city people, particularly the suburban people, than those of the nonfarm rural or non- metropolitan people. When all nonfarmers are collapsed into one group, the differences between farmers and nonfarmers are discernable but not statistically significant.

A final issue is whether differences in attitudes and morals between farmers and nonfarmers are widening on converging over time. Annex Table 18 shows statistical results of the seventeen variables in which the time trend was examined. A significant difference was found only for political party affiliation. Party affiliation of farmers is becoming more like others over time. In most traits, however, the socio-psychological differences between farmers and nonfarmers, where they exist, do not seem to be converging over time.

\section{Conclusions}

The evidence supports several assumptions of farm fundamentalism examined in this paper. Compared to the general population, the typical farmer has higher morals, is politically more conservative and is happier and more satisfied with some aspects of life including work (see Table 1). Farmers have not lost their uniqueness. As a group, farmers are among the better-adjusted members of society. They are optimistic and have a healthy outlook on life both in terms of interpersonal relationships and general viewpoint.

We cannot necessarily conclude, however, that there is a significant difference among residence groups in overall quality of life. Differences among respondents are explained mainly by differences in age, education, and health rather than by place of residence (Blue and Tweeten, 1994). Using the same set as in this study but correcting for income, age, and health, Blue and Tweeten found no statistically significant effect of residence on a farm or in a rural area on overall quality of life.

This finding also is consistent with an earlier review of studies of quality of life of farms by Coughenour and Tweeten. They concluded that any advantage for farm residents registered in sociopsychological measures of satisfaction with work, family, and the like as found in this study were offset by dissatisfaction with economic outcomes. The conclusion is that farm people display unique social characteristics but their overall quality of life is not necessarily superior to that of others. 
The favorable farm attitudes and morals are a positive force in American society but a relatively small and declining farm population means that farmers may less influence than be influ- enced by the large nonfarm population. Just how the different attitudes and morals of farmers found in this study effect society is a topic for further research. 


\section{References}

Blue, E. Neal and Luther Tweeten. "The Estimation of Marginal Utility of Income for Application to Agricultural Policy Analysis." ESO 2160. Columbus: Department of Agricultural Economics, The Ohio State University, 1994.

Coughenour, C. Milton and Luther Tweeten. "Quality of Life Perceptions and Farm Structure." Chapter 5 in Joseph Molnar, ed., Agricultural Change. Boulder, CO: Westview Press, 1986.

Jose, H. Douglas and James A. Crumly. "Psychological Type and Its Influence on Farm/Ranch Decision Making." Review of Agricultural Economics, 15(1):121-132.

National Opinion Research Center. General Social Surveys, 1972-1993: Cumulative Code Book. Chicago: NORC, University of Chicago, August, 1993.

Paarlberg, Don. "Agriculture Loses Its Uniqueness." American Journal of AgriculturalEconomics, 60(1978):76976.

Seeman, Melvin. "Alienation and Anomie." Chapter 7 in Measures of Personality and Social Psychological Attitudes, John P. Robinson, Phillip R. Shaver, and Lawrence S. Wrightsman, eds. San Diego: Academic Press, 1991.

Tweeten, Luther. Farm Policy Analysis. Boulder, CO: Westview Press, 1989.

U.S. Department of Agriculture. Economic Indicators of the Farm Sector: National Financial Summary. 1993. ECIF-13-1. Washington, DC: Economic Research Service, USDA. 


\section{Annex}

Table

Morality

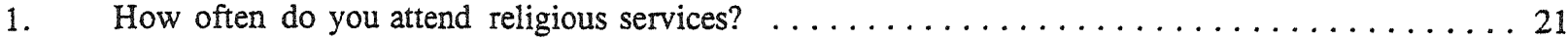

2. Would you call yourself a strong [religious preference]

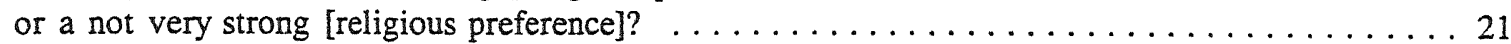

3. Were you ever picked up, or charged, by the police, for any reason

whether or not you were guilty (other than traffic violation)? $\ldots \ldots \ldots \ldots \ldots \ldots \ldots \ldots \ldots \ldots \ldots \ldots$

4. With whom were you living with around the time you were $16 ? \ldots \ldots \ldots \ldots \ldots \ldots \ldots 22$

5. Have you ever been divorced or legally separated? $\ldots \ldots \ldots \ldots \ldots \ldots \ldots \ldots \ldots \ldots \ldots \ldots$

6. Taking things all together, how would you describe you marriage? $\ldots \ldots \ldots \ldots \ldots \ldots \ldots \ldots$

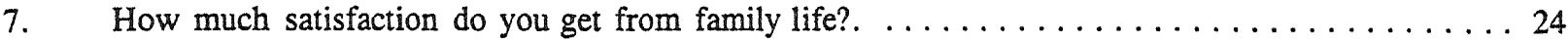

8. How much satisfaction do you get from you friendships?. . . . . . . . . . . . . . . 24

\section{Political Ideology}

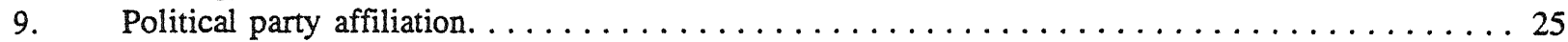

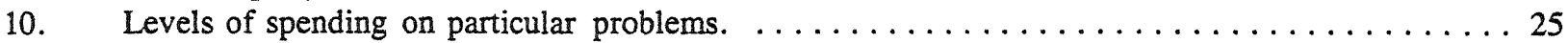

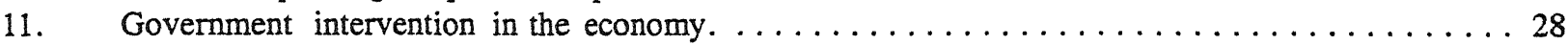

\section{Work Ethic}

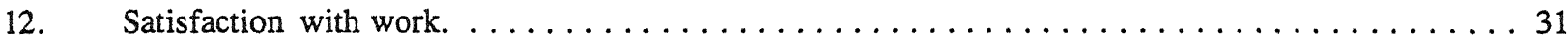

13. If you were to get enough money to live as comfortably as you would like for the rest of your life, would you continue to work

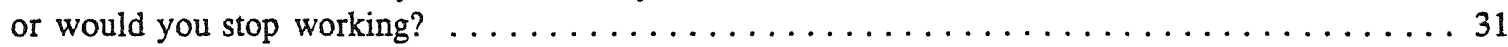

14. Importance of various attributes for getting ahead in life....................... 32

15. Some people say that people get ahead by their own hard work; others say that lucky breaks or help from other people are more

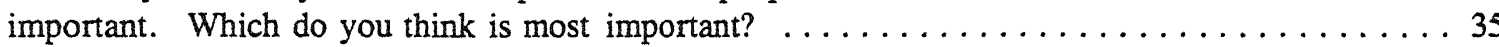

\section{Outlook on Life}

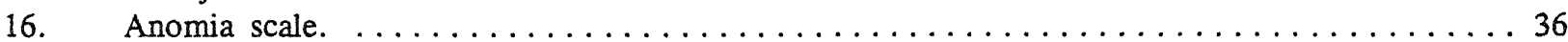

17. Taken all together, how would you say things are these days - would you say that you are very happy, pretty happy, or not too happy?

18. Regression results of nonfarmer-farmer differences. 


\section{Morality}

Table 1. How often do you attend religious services?

\begin{tabular}{|c|c|c|c|c|c|c|}
\hline Response & Farmers & Nonfarm rural & Non-metropolitan & Suburban & Medium city & Large city \\
\hline & \multicolumn{6}{|c|}{$\begin{array}{c}\text { percent } \\
\text { (total number responding) }\end{array}$} \\
\hline Never & 10.17 & 12.37 & 11.58 & 13.70 & 12.98 & 15.89 \\
\hline Less than once a year & 8.75 & 7.56 & 7.72 & 8.05 & 7.47 & 7.25 \\
\hline Once or twice a year & 8.51 & 12.28 & 11.90 & 13.74 & 12.61 & 14.31 \\
\hline Several times a year & 11.11 & 12.09 & 12.21 & 13.87 & 12.30 & 14.48 \\
\hline Once a month & 10.17 & 7.12 & 7.64 & 7.28 & 7.47 & 7.08 \\
\hline Two or three times a month & 11.11 & 8.80 & 9.64 & 8.69 & 10.21 & 8.98 \\
\hline Nearly every week & 9.93 & 6.95 & 7.46 & 5.15 & 5.61 & 5.27 \\
\hline Every week & 22.93 & 22.96 & 23.05 & 22.48 & 23.28 & 19.64 \\
\hline $\begin{array}{l}\text { Several times a week } \\
\chi^{2}=216.5, \text { prob. }=0.00\end{array}$ & $\begin{array}{r}7.33 \\
(423)\end{array}$ & $\begin{array}{c}9.91 \\
(4,592)\end{array}$ & $\begin{array}{c}8.81 \\
(3,497)\end{array}$ & $\begin{array}{c}7.04 \\
(11,619)\end{array}$ & $\begin{array}{c}8.08 \\
(2,959)\end{array}$ & $\begin{array}{c}7.10 \\
(5,311)\end{array}$ \\
\hline
\end{tabular}

${ }^{2}$ Sample response numbers in parentheses below percentage responses in this and subsequent tables.

The statistical test for the two-group comparison of farmers versus nonfarmers is $\chi^{2}=31.8$, prob. $=0.00$. The $\chi^{2}$ in the table tests the null hypothesis that the response patterns is the same among the six residence groups.

Table 2. Would you call yourself a strong [religious preference] or a not very strong [religious preference].

\begin{tabular}{|c|c|c|c|c|c|c|}
\hline Response & Farmers & Nonfarm rural & Non-metropolitan & Suburban & Medium city & Large city \\
\hline \multirow{6}{*}{$\begin{array}{l}\text { Strong } \\
\text { Somewhat strong } \\
\text { Not very strong } \\
\chi^{2}=83.3 \text {, prob. }=0.00\end{array}$} & \multicolumn{6}{|c|}{$\begin{array}{c}\text { percent } \\
\text { (total number responding) }\end{array}$} \\
\hline & 47.87 & 44.79 & 44.72 & 40.34 & 44.97 & 42.81 \\
\hline & 18.29 & 10.34 & 12.17 & 10.63 & 11.22 & 11.01 \\
\hline & 33.84 & 44.87 & 43.10 & 49.03 & 43.81 & 46.18 \\
\hline & $(328)$ & $(3,780)$ & $(2,842)$ & $(9,501)$ & $(2,335)$ & $(3,987)$ \\
\hline & & & & & & \\
\hline
\end{tabular}

For farmers versus nonfarmers, $\chi^{2}=29.4$, prob. $=0.00$. 
Table 3. Were you ever picked up, or charged, by the police, for any reason whether or not you were guilty (other than traffic violation)?

\begin{tabular}{|c|c|c|c|c|c|c|}
\hline Response & Farmers & Nonfarm rural & Non-metropolitan & Suburban & Medium city & Large city \\
\hline \multirow{5}{*}{$\begin{array}{l}\text { Yes } \\
\text { No } \\
\chi^{2}=49.9, \text { prob. }=0.00\end{array}$} & \multicolumn{6}{|c|}{$\begin{array}{c}\text { percent } \\
\text { (total number responding) }\end{array}$} \\
\hline & 9.09 & 8.63 & 7.95 & 11.44 & 12.94 & 14.19 \\
\hline & 90.94 & 91.37 & 92.05 & 88.56 & 87.06 & 85.81 \\
\hline & (176) & $(1,911)$ & $(1,271)$ & $(3,987)$ & $(1,090)$ & $(2,159)$ \\
\hline & & & & & & \\
\hline
\end{tabular}

For farmer versus nonfarmers, $\chi^{2}=0.8$, prob. $=0.37$.

Table 4. With whom were you living with around the time you were 16 ?

\begin{tabular}{|c|c|c|c|c|c|c|}
\hline Response & Farmers & Nonfarm rural & Non-metropolitan & Suburban & Medium city & Large city \\
\hline \multirow{6}{*}{$\begin{array}{l}\text { Own mother and father } \\
\text { Father or mother and stepparent } \\
\text { Father or mother only } \\
\text { Other female or male relative }\end{array}$} & \multicolumn{6}{|c|}{$\begin{array}{c}\text { percent } \\
\text { (total number responding) }\end{array}$} \\
\hline & 85.68 & 79.16 & 77.69 & 77.61 & 71.82 & 69.94 \\
\hline & 3.82 & 6.08 & 5.85 & 5.49 & 7.28 & 6.85 \\
\hline & 7.16 & 10.80 & 12.81 & 13.27 & 15.04 & 17.02 \\
\hline & 3.34 & 3.97 & 3.65 & 3.63 & 5.87 & 6.20 \\
\hline & $(419)$ & $(4,539)$ & $(3,451)$ & $(11,458)$ & $(2,913)$ & $(5,242)$ \\
\hline$\chi^{2}=237.6$, prob. $=0.00$ & & & & & & \\
\hline
\end{tabular}

For farmers versus nonfarmers, $\chi^{2}=22.8$, prob. $=0.00$. 
Table 5. Have you ever been divorced or legally separated?

\begin{tabular}{|c|c|c|c|c|c|c|}
\hline Response & Farmers & Nonfarm rural & Non-metropolitan & Suburban & Medium city & Large city \\
\hline & \multicolumn{6}{|c|}{$\begin{array}{c}\text { percent } \\
\text { (total number responding) }\end{array}$} \\
\hline Yes & 12.93 & 24.18 & 27.73 & 28.64 & 35.04 & 38.30 \\
\hline No & 87.07 & 75.82 & 72.27 & 71.36 & 64.96 & 61.70 \\
\hline$\chi^{2}=295.1$, prob. $=0.00$ & & & $(2,900)$ & $(9,114)$ & $(2,3 / 7)$ & \\
\hline
\end{tabular}

For farmers versus nonfarmers, $\chi^{2}=52.4$, prob. $=0.00$.

Table 6. Taking things all together, how would you describe you marriage?

\begin{tabular}{|c|c|c|c|c|c|c|}
\hline Response & Farmers & Nonfarm rural & Non-metropolitan & Suburban & Medium city & Large City \\
\hline \multirow{6}{*}{$\begin{array}{l}\text { Very happy } \\
\text { Pretty happy } \\
\text { Not too happy } \\
\chi^{2}=54.3 \text {, prob. }=0.00\end{array}$} & \multicolumn{6}{|c|}{$\begin{array}{c}\text { percent } \\
\text { (total number responding) }\end{array}$} \\
\hline & 65.83 & 64.88 & 64.95 & 65.69 & 62.39 & 61.21 \\
\hline & 32.01 & 32.39 & 32.10 & 31.75 & 35.36 & 33.68 \\
\hline & 2.16 & 2.73 & 2.95 & 2.56 & 2.26 & 5.11 \\
\hline & $(278)$ & $(2,930)$ & $(2,003)$ & $(6,986)$ & $(1,417)$ & $(2,230)$ \\
\hline & & & & & & \\
\hline
\end{tabular}

For farmer versus nonfarmers, $\chi^{2}=0.7$, prob. $=0.70$. 
Table 7. How much satisfaction do you get from family life?

\begin{tabular}{|c|c|c|c|c|c|c|}
\hline Response & Farmers & Nonfarm rural & Non-metropolitan & Suburban & Medium city & Large city \\
\hline & \multicolumn{6}{|c|}{ percent } \\
\hline A very great deal & 42.26 & 43.58 & 43.56 & 43.95 & 38.75 & 36.70 \\
\hline A great deal & 36.90 & 34.53 & 32.39 & 33.35 & 33.74 & 32.10 \\
\hline Quite a bit & 11.61 & 9.34 & 10.85 & 10.49 & 11.88 & 12.04 \\
\hline A fair amount & 5.06 & 5.96 & 7.53 & 6.53 & 7.67 & 9.21 \\
\hline Some & 1.79 & 3.11 & 2.71 & 2.39 & 3.33 & 3.98 \\
\hline A little & 1.49 & 2.12 & 1.64 & 1.81 & 2.11 & 3.22 \\
\hline \multirow{3}{*}{$\begin{array}{l}\text { None } \\
\chi^{2}=217.5, \text { prob. }=0.00 .\end{array}$} & 0.89 & 1.36 & 1.32 & 1.49 & 2.53 & 2.74 \\
\hline & (336) & $(3,823)$ & $(2,803)$ & $(9,359)$ & $(2,374)$ & $(4,343)$ \\
\hline & & & & & & \\
\hline
\end{tabular}

For farmers versus nonfarmers, $\chi^{2}=7.4$, prob. $=0.29$.

Table 8. How much satisfaction do you get from you friendships?

\begin{tabular}{|c|c|c|c|c|c|c|}
\hline Response & Farmers & Nonfarm rural & Non-metropolitan & Suburban & Medium city & Large city \\
\hline & \multicolumn{6}{|c|}{$\begin{array}{c}\text { percent } \\
\text { (total number responding) }\end{array}$} \\
\hline A very great deal & 35.80 & 31.67 & 30.06 & 31.14 & 29.14 & 26.72 \\
\hline A great deal & 42.90 & 40.51 & 40.34 & 39.95 & 38.79 & 37.68 \\
\hline Quite a bit & 13.02 & 14.49 & 14.91 & 15.08 & 15.16 & 16.38 \\
\hline A fair amount & 6.51 & 8.71 & 9.06 & 8.69 & 10.54 & 11.44 \\
\hline Some & 1.18 & 2.42 & 2.89 & 3.03 & 2.98 & 3.65 \\
\hline A little & 0.59 & 1.67 & 2.21 & 1.58 & 2.69 & 2.85 \\
\hline \multirow{3}{*}{$\chi^{2}=154.5$, prob. $=0.00$} & 0.00 & 0.52 & 0.53 & 0.53 & 0.71 & 1.29 \\
\hline & (338) & $(3,836)$ & $(2,804)$ & $(9,379)$ & $(2,382)$ & $(4,353)$ \\
\hline & & & & & & \\
\hline
\end{tabular}

For farmers versus nonfarmers, $\chi^{2}=18.3$, prob. $=0.01$. 


\section{Political Ideology}

Table 9. Political party affiliation.

\begin{tabular}{|c|c|c|c|c|c|c|}
\hline Response & Farmers & Nonfarm rural & Non-metropolitan & Suburban & Medium city & Large city \\
\hline & \multicolumn{6}{|c|}{ percent } \\
\hline Strong Democrat & 19.85 & 15.02 & 16.59 & 13.55 & 19.80 & 24.48 \\
\hline Not very strong Democrat & 18.40 & 25.54 & 23.54 & 22.27 & 25.41 & 27.07 \\
\hline Independent, close to Democrat & 5.81 & 10.08 & 12.16 & 12.65 & 13.47 & 13.19 \\
\hline Independent & 8.23 & 13.13 & 13.05 & 12.54 & 11.46 & 11.65 \\
\hline Independent, close to Republican & 8.23 & 9.49 & 9.13 & 10.11 & 8.55 & 6.10 \\
\hline Not very strong Republican & 24.21 & 17.81 & 16.91 & 18.35 & 14.16 & 11.02 \\
\hline \multirow{3}{*}{$\begin{array}{l}\text { Strong Republican } \\
\chi^{2}=692.7, \text { prob. }=0.00\end{array}$} & 15.25 & 8.94 & 8.61 & 10.53 & 7.15 & 6.50 \\
\hline & (413) & $(4,554)$ & $(3,471)$ & $(11,513)$ & $(2,924)$ & $(5,217)$ \\
\hline & & & & & & \\
\hline
\end{tabular}

For farmers versus nonfarmers, $\chi^{2}=61.9$, prob. $=0.00$.

Table 10. Levels of spending on particular problems.

\begin{tabular}{|c|c|c|c|c|c|c|c|}
\hline Response item & Response & Farmers & Nonfarm rural & Non-metropolitan & Suburban & Medium city & Large city \\
\hline \multirow{4}{*}{$\begin{array}{l}\text { Space exploration } \\
\chi^{2}=82.7 \\
\text { prob. }=0.00\end{array}$} & \multirow{4}{*}{$\begin{array}{l}\text { Too little } \\
\text { About right } \\
\text { Too much }\end{array}$} & \multicolumn{6}{|c|}{$\begin{array}{c}\text { percent } \\
\text { (total number responding) }\end{array}$} \\
\hline & & 6.06 & 10.04 & 12.22 & 14.76 & 11.77 & 11.90 \\
\hline & & 40.91 & 39.67 & 41.97 & 48.01 & 43.88 & 38.99 \\
\hline & & $\begin{array}{l}53.03 \\
(66)\end{array}$ & $\begin{array}{l}50.29 \\
(857)\end{array}$ & $\begin{array}{l}45.82 \\
(753)\end{array}$ & $\begin{array}{c}37.23 \\
(2,812)\end{array}$ & $\begin{array}{l}44.34 \\
(654)\end{array}$ & $\begin{array}{c}49.11 \\
(1,067)\end{array}$ \\
\hline The environment & Too little & 33.33 & 60.17 & 65.68 & 67.66 & 67.53 & 71.53 \\
\hline$\chi^{2}=68.2$ & About right & 56.06 & 31.21 & 28.02 & 26.81 & 25.42 & 22.74 \\
\hline prob. $=0.00$ & Too much & 10.61 & 8.63 & 6.30 & 5.53 & 7.04 & 5.73 \\
\hline & & $(66)$ & $(846)$ & $(746)$ & $(2,786)$ & $(653)$ & $(1,082)$ \\
\hline
\end{tabular}


Table 10 continued.

\begin{tabular}{|c|c|c|c|c|c|c|c|}
\hline Response item & Response & Farmers & Nonfarm rural & Non-metropolitan & Suburban & Medium city & Large city \\
\hline $\begin{array}{l}\text { Health } \\
\chi^{2}=39.4 \\
\text { prob. }=0.00\end{array}$ & $\begin{array}{l}\text { Too little } \\
\text { About right } \\
\text { Too much }\end{array}$ & $\begin{array}{l}47.06 \\
44.12 \\
8.82 \\
(68)\end{array}$ & $\begin{array}{c}63.13 \\
29.09 \\
7.78 \\
(887)\end{array}$ & $\begin{array}{c}67.96 \\
26.74 \\
5.30 \\
(774)\end{array}$ & $\begin{array}{c}65.39 \\
27.13 \\
7.48 \\
(2,846)\end{array}$ & $\begin{array}{c}67.67 \\
26.47 \\
5.86 \\
(665)\end{array}$ & $\begin{array}{c}72.11 \\
22.74 \\
5.14 \\
(1,108)\end{array}$ \\
\hline $\begin{array}{l}\text { Assistance to big } \\
\text { cities } \\
\chi^{2}=305.5 \\
\text { prob. }=0.00\end{array}$ & $\begin{array}{l}\text { Too little } \\
\text { About right } \\
\text { Too much }\end{array}$ & $\begin{array}{c}10.91 \\
36.36 \\
52.73 \\
(55)\end{array}$ & $\begin{array}{l}13.65 \\
36.49 \\
49.86 \\
(740)\end{array}$ & $\begin{array}{l}15.61 \\
39.70 \\
44.70 \\
(660)\end{array}$ & $\begin{array}{c}21.43 \\
43.77 \\
34.80 \\
(2,552)\end{array}$ & $\begin{array}{l}27.18 \\
40.00 \\
32.82 \\
(585)\end{array}$ & $\begin{array}{c}40.54 \\
36.47 \\
22.99 \\
(1,009)\end{array}$ \\
\hline $\begin{array}{l}\text { Law enforcement } \\
\chi^{2}=35.3 \\
\text { prob. }=0.00\end{array}$ & $\begin{array}{l}\text { Too little } \\
\text { About right } \\
\text { Too much }\end{array}$ & $\begin{array}{l}44.12 \\
42.65 \\
13.24 \\
(68)\end{array}$ & $\begin{array}{c}54.48 \\
37.57 \\
7.95 \\
(881)\end{array}$ & $\begin{array}{c}52.49 \\
40.31 \\
7.20 \\
(764)\end{array}$ & $\begin{array}{c}56.83 \\
37.73 \\
5.44 \\
(2,833)\end{array}$ & $\begin{array}{c}60.49 \\
32.22 \\
7.29 \\
(658)\end{array}$ & $\begin{array}{c}60.55 \\
33.06 \\
6.39 \\
(1,095)\end{array}$ \\
\hline $\begin{array}{l}\text { Drug rehabilitation } \\
\chi^{2}=70.4 \\
\text { prob. }=0.00\end{array}$ & $\begin{array}{l}\text { Too little } \\
\text { About right } \\
\text { Too much }\end{array}$ & $\begin{array}{c}43.75 \\
35.94 \\
20.31 \\
(64)\end{array}$ & $\begin{array}{l}60.90 \\
28.50 \\
10.60 \\
(849)\end{array}$ & $\begin{array}{c}57.84 \\
33.47 \\
8.70 \\
(759)\end{array}$ & $\begin{array}{c}57.09 \\
33.62 \\
9.29 \\
(2,778)\end{array}$ & $\begin{array}{c}64.42 \\
28.22 \\
7.36 \\
(652)\end{array}$ & $\begin{array}{c}68.94 \\
23.88 \\
7.18 \\
(1,072)\end{array}$ \\
\hline $\begin{array}{l}\text { Education } \\
\chi^{2}=43.7 \\
\text { prob. }=0.00\end{array}$ & $\begin{array}{l}\text { Too little } \\
\text { About right } \\
\text { Too much }\end{array}$ & $\begin{array}{l}42.65 \\
45.59 \\
11.76 \\
(68)\end{array}$ & $\begin{array}{c}66.67 \\
28.33 \\
5.00 \\
(900)\end{array}$ & $\begin{array}{c}66.75 \\
27.24 \\
6.01 \\
(782)\end{array}$ & $\begin{array}{c}69.79 \\
25.09 \\
5.12 \\
(2,890)\end{array}$ & $\begin{array}{c}72.39 \\
23.28 \\
4.33 \\
(670)\end{array}$ & $\begin{array}{c}73.74 \\
22.03 \\
4.23 \\
(1,112)\end{array}$ \\
\hline $\begin{array}{l}\text { Assistance to } \\
\text { blacks } \\
\chi^{2}=290.5 \\
\text { prob. }=0.00\end{array}$ & $\begin{array}{l}\text { Too little } \\
\text { About right } \\
\text { Too much }\end{array}$ & $\begin{array}{c}7.69 \\
56.92 \\
35.38 \\
(65)\end{array}$ & $\begin{array}{l}20.15 \\
47.64 \\
32.21 \\
(804)\end{array}$ & $\begin{array}{l}26.80 \\
47.81 \\
25.39 \\
(709)\end{array}$ & $\begin{array}{c}26.71 \\
47.03 \\
26.26 \\
(2,677)\end{array}$ & $\begin{array}{l}40.22 \\
42.79 \\
16.99 \\
(624)\end{array}$ & $\begin{array}{c}48.95 \\
34.99 \\
16.06 \\
(1,046)\end{array}$ \\
\hline $\begin{array}{l}\text { National defense } \\
\chi^{2}=54.1 \\
\text { prob. }=0.00\end{array}$ & $\begin{array}{l}\text { Too little } \\
\text { About right } \\
\text { Too much }\end{array}$ & $\begin{array}{c}9.38 \\
56.25 \\
34.38 \\
(64)\end{array}$ & $\begin{array}{l}19.74 \\
44.48 \\
35.77 \\
(861)\end{array}$ & $\begin{array}{l}17.29 \\
47.87 \\
34.84 \\
(752)\end{array}$ & $\begin{array}{c}15.34 \\
46.65 \\
38.01 \\
(2,810)\end{array}$ & $\begin{array}{l}16.24 \\
42.49 \\
41.27 \\
(659)\end{array}$ & $\begin{array}{c}14.01 \\
38.87 \\
47.12 \\
(1,078)\end{array}$ \\
\hline
\end{tabular}


Table 10 continued.

\begin{tabular}{|c|c|c|c|c|c|c|c|}
\hline Response item & Response & Farmers & Nonfarm rural & Non-metropolitan & Suburban & Medium city & Large city \\
\hline \multirow{4}{*}{$\begin{array}{l}\text { Assistance to other } \\
\text { countries } \\
\chi^{2}=33.6 \\
\text { prob. }=0.00\end{array}$} & Too little & 4.41 & 4.54 & 3.12 & 5.10 & 5.96 & 6.62 \\
\hline & About right & 19.12 & 16.91 & 15.86 & 21.12 & 21.16 & 21.25 \\
\hline & Too much & 76.47 & 78.55 & 81.01 & 73.78 & 72.88 & 72.13 \\
\hline & & $(68)$ & $(881)$ & (769) & $(2,822)$ & $(671)$ & $(1,087)$ \\
\hline \multirow{4}{*}{$\begin{array}{l}\text { Assistance to the } \\
\text { poor } \\
\chi^{2}=54.3 \\
\text { prob. }=0.00\end{array}$} & Too little & 46.27 & 64.71 & 67.19 & 64.46 & 70.85 & 74.12 \\
\hline & About right & 38.81 & 25.00 & 24.38 & 25.90 & 21.38 & 19.00 \\
\hline & Too much & 14.93 & 10.29 & 8.43 & 9.64 & 7.77 & 6.88 \\
\hline & & $(67)$ & $(884)$ & $(771)$ & $(2,873)$ & $(669)$ & $(1,105)$ \\
\hline
\end{tabular}

The $\chi^{2} s$ for farmers versus nonfarmers are as follows:

$\begin{array}{lrr} & \chi^{2} & \text { prob. } \\ & 4.1 & 0.13 \\ \text { Space exploration } & 33.9 & 0.00 \\ \text { The environment } & 12.2 & 0.00 \\ \text { Health } & 8.5 & 0.01 \\ \text { Assistance to big cities } & 7.5 & 0.02 \\ \text { Law enforcement } & 12.9 & 0.00 \\ \text { Drug rehabilitation } & 24.5 & 0.00 \\ \text { Education } & 17.0 & 0.00 \\ \text { Assistance to blacks } & 4.0 & 0.13 \\ \text { National defense } & 0.1 & 0.95 \\ \text { Assistance to other countries } & 13.1 & 0.00 \\ \text { Assistance to the poor } & & \end{array}$


Table 11. Government intervention in the economy.

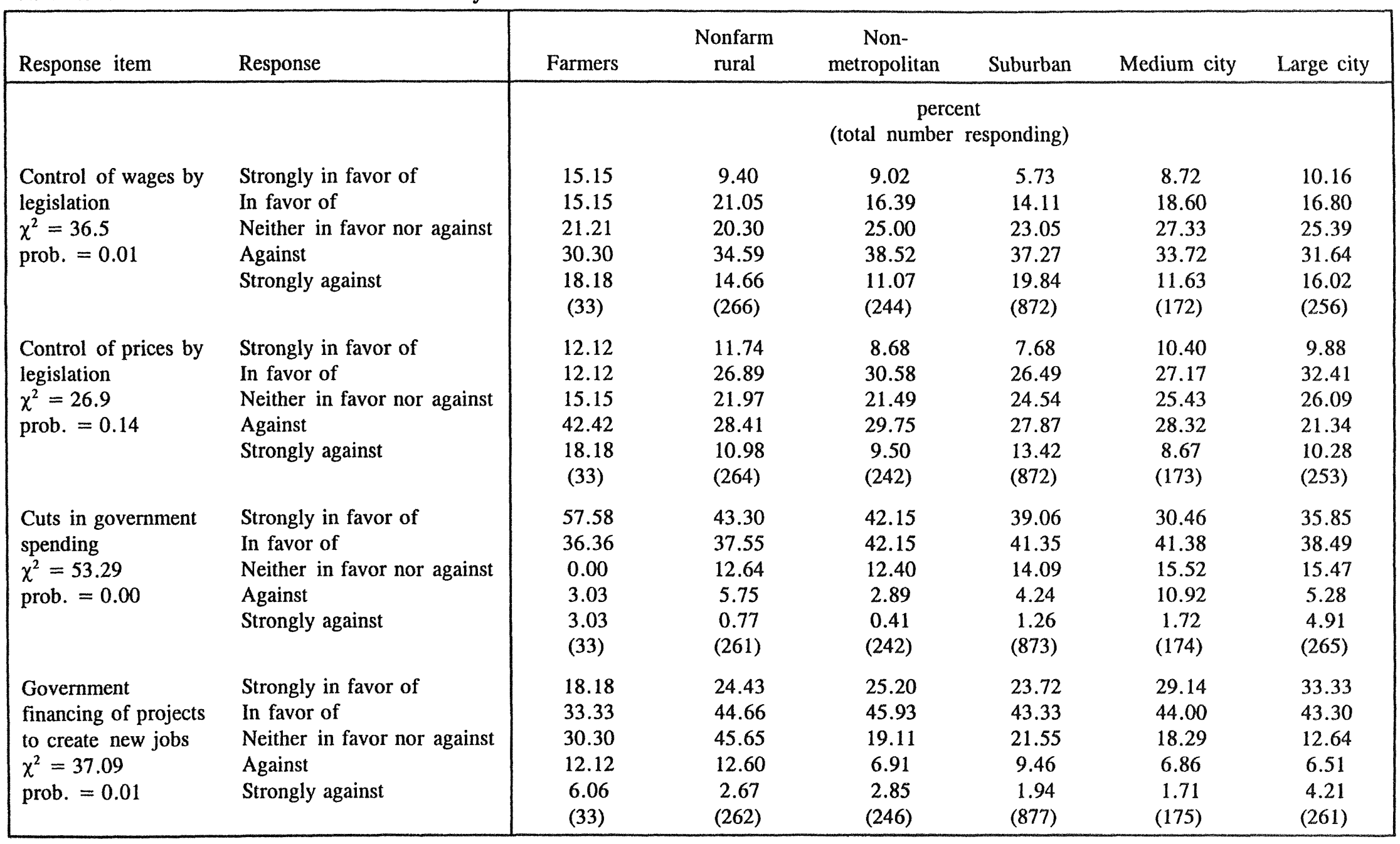


Table 11 continued.

\begin{tabular}{|c|c|c|c|c|c|c|c|}
\hline Response item & Response & Farmers & $\begin{array}{l}\text { Nonfarm } \\
\text { rural }\end{array}$ & $\begin{array}{c}\text { Non- } \\
\text { metropolitan }\end{array}$ & Suburban & Medium city & Large city \\
\hline $\begin{array}{l}\text { Less government } \\
\text { regulation of } \\
\text { business } \\
\chi^{2}=34.7 \\
\text { prob. }=0.02\end{array}$ & $\begin{array}{l}\text { Strongly in favor of } \\
\text { In favor of } \\
\text { Neither in favor nor against } \\
\text { Against } \\
\text { Strongly against }\end{array}$ & $\begin{array}{l}21.88 \\
37.50 \\
25.00 \\
15.63 \\
0.00 \\
(32)\end{array}$ & $\begin{array}{c}14.50 \\
33.97 \\
32.44 \\
16.41 \\
2.67 \\
(262)\end{array}$ & $\begin{array}{c}11.43 \\
32.65 \\
39.18 \\
14.69 \\
2.04 \\
(245)\end{array}$ & $\begin{array}{c}13.99 \\
33.94 \\
35.21 \\
13.76 \\
3.10 \\
(872)\end{array}$ & $\begin{array}{c}13.22 \\
28.16 \\
35.06 \\
20.69 \\
2.87 \\
(174)\end{array}$ & $\begin{array}{c}11.33 \\
23.44 \\
42.97 \\
15.63 \\
6.64 \\
(256)\end{array}$ \\
\hline $\begin{array}{l}\text { Support for industry } \\
\text { to develop new } \\
\text { products and } \\
\text { technology } \\
\chi^{2}=26.0 \\
\text { prob. }=0.16\end{array}$ & $\begin{array}{l}\text { Strongly in favor of } \\
\text { In favor of } \\
\text { Neither in favor nor against } \\
\text { Against } \\
\text { Strongly against }\end{array}$ & $\begin{array}{l}15.15 \\
54.55 \\
15.15 \\
9.09 \\
6.06 \\
(33)\end{array}$ & $\begin{array}{c}21.89 \\
53.96 \\
14.72 \\
7.17 \\
2.26 \\
(265)\end{array}$ & $\begin{array}{c}25.71 \\
47.76 \\
19.18 \\
5.71 \\
1.63 \\
(245)\end{array}$ & $\begin{array}{c}25.29 \\
47.94 \\
19.34 \\
6.41 \\
1.03 \\
(874)\end{array}$ & $\begin{array}{c}24.00 \\
48.00 \\
22.86 \\
4.57 \\
0.57 \\
(175)\end{array}$ & $\begin{array}{c}26.15 \\
41.92 \\
24.62 \\
5.00 \\
2.31 \\
(260)\end{array}$ \\
\hline $\begin{array}{l}\text { Supporting declining } \\
\text { industries to protect } \\
\text { jobs } \\
\chi^{2}=39.5 \\
\text { prob. }=0.00\end{array}$ & $\begin{array}{l}\text { Strongly in favor of } \\
\text { In favor of } \\
\text { Neither in favor nor against } \\
\text { Against } \\
\text { Strongly against }\end{array}$ & $\begin{array}{c}6.06 \\
33.33 \\
18.18 \\
30.30 \\
12.12 \\
(33)\end{array}$ & $\begin{array}{c}19.47 \\
38.17 \\
23.28 \\
13.74 \\
5.34 \\
(262)\end{array}$ & $\begin{array}{c}15.85 \\
40.65 \\
23.98 \\
16.67 \\
2.85 \\
(246)\end{array}$ & $\begin{array}{c}14.50 \\
32.65 \\
28.31 \\
20.66 \\
3.88 \\
(876)\end{array}$ & $\begin{array}{c}16.00 \\
40.00 \\
25.71 \\
16.57 \\
1.71 \\
(175)\end{array}$ & $\begin{array}{c}18.32 \\
35.88 \\
26.34 \\
13.36 \\
6.11 \\
(262)\end{array}$ \\
\hline $\begin{array}{l}\text { Reducing the work } \\
\text { week to create more } \\
\text { jobs } \\
\chi^{2}=25.9 \\
\text { prob. }=0.17\end{array}$ & $\begin{array}{l}\text { Strongly in favor of } \\
\text { In favor of } \\
\text { Neither in favor nor against } \\
\text { Against } \\
\text { Strongly against }\end{array}$ & $\begin{array}{c}3.13 \\
21.88 \\
18.75 \\
31.25 \\
25.00 \\
(32)\end{array}$ & $\begin{array}{c}7.28 \\
19.54 \\
27.20 \\
34.48 \\
11.49 \\
(261)\end{array}$ & $\begin{array}{c}6.50 \\
17.07 \\
30.49 \\
36.18 \\
9.76 \\
(246)\end{array}$ & $\begin{array}{c}6.74 \\
16.34 \\
34.40 \\
30.51 \\
12.00 \\
(875)\end{array}$ & $\begin{array}{c}6.82 \\
18.75 \\
34.66 \\
28.98 \\
10.80 \\
(176)\end{array}$ & $\begin{array}{l}11.24 \\
20.16 \\
29.07 \\
29.46 \\
10.08 \\
(258)\end{array}$ \\
\hline
\end{tabular}


The $\chi^{2}$ s for farmers versus nonfarmers are as follows:

Control of wages by legislation

Control of prices by legislation

$8.2-0.08$

Cuts in government spending

$8.3 \quad 0.08$

Government financing of projects to create new jobs

$5.9-0.21$

Less government regulation of business

$4.3 \quad 0.37$

Support for industry to develop new products and technology

$\begin{array}{ll}7.0 & 0.14\end{array}$

Supporting declining industries to protect jobs

$10.8 \quad 0.03$

Reducing the work week to create more jobs 
Work Ethic

Table 12. Satisfaction with work.

\begin{tabular}{|c|c|c|c|c|c|c|}
\hline Response & Farmers & Nonfarm rural & Non-metropolitan & Suburban & Medium city & Large city \\
\hline & \multicolumn{6}{|c|}{$\begin{array}{c}\text { percent } \\
\text { (total number responding) }\end{array}$} \\
\hline Very satisfied & 59.45 & 49.35 & 48.09 & 49.00 & 45.87 & 43.45 \\
\hline Moderately satisfied & 31.50 & 37.68 & 38.07 & 37.07 & 38.23 & 38.91 \\
\hline A little dissatisfied & 7.87 & 9.08 & 9.62 & 9.84 & 10.75 & 11.98 \\
\hline \multirow{3}{*}{$\begin{array}{l}\text { Very dissatisfied } \\
\chi^{2}=84.6, \text { prob. }=0.00\end{array}$} & 1.18 & 3.90 & 4.22 & 4.09 & 5.16 & 5.66 \\
\hline & $(254)$ & $(3,591)$ & $(2,703)$ & $(9,546)$ & $(2,289)$ & $(4,099)$ \\
\hline & & & & & & \\
\hline
\end{tabular}

For farmers versus nonfarmers, $\chi^{2}=17.4$, prob. $=0.00$.

Table 13. If you were to get enough money to live as comfortably as you would like for the rest of your life, would you continue to work or would you stop working?

\begin{tabular}{|c|c|c|c|c|c|c|c|}
\hline Response & Farmers & & Nonfarm rural & Non-metropolitan & Suburban & Medium city & Large city \\
\hline \multirow{3}{*}{$\begin{array}{l}\text { Continue } \\
\text { Stop } \\
\chi^{2}=20.3 \text {, prob. }=0.00\end{array}$} & \multicolumn{7}{|c|}{$\begin{array}{c}\text { percent } \\
\text { (total number responding) }\end{array}$} \\
\hline & 86.49 & & 72.47 & 70.70 & 70.86 & 72.78 & 70.52 \\
\hline & $\begin{array}{l}13.51 \\
(148)\end{array}$ & 1 & $\begin{array}{c}27.53 \\
(14.69)\end{array}$ & $\begin{array}{c}29.30 \\
(1,290)\end{array}$ & $\begin{array}{c}29.14 \\
(4,836)\end{array}$ & $\begin{array}{c}27.22 \\
(1,183)\end{array}$ & $\begin{array}{c}29.48 \\
(2,144)\end{array}$ \\
\hline
\end{tabular}

For farmers versus nonfarmers, $\chi^{2}=16.7$, prob. $=0.00$. 
Table 14. Importance of various attributes for getting ahead in life.

\begin{tabular}{|c|c|c|c|c|c|c|c|}
\hline Response item & Response & Farmers & Nonfarm rural & Non-metropolitan & Suburban & Medium city & Large city \\
\hline \multirow{7}{*}{$\begin{array}{l}\text { Coming from a } \\
\text { wealthy family } \\
\chi^{2}=39.7 \\
\text { prob. }=0.01\end{array}$} & \multirow{7}{*}{$\begin{array}{l}\text { Essential } \\
\text { Very important } \\
\text { Fairly important } \\
\text { Not very important } \\
\text { Not important at all }\end{array}$} & \multicolumn{6}{|c|}{$\begin{array}{c}\text { percent } \\
\text { (total number responding) }\end{array}$} \\
\hline & & 0.00 & 5.29 & 3.45 & 3.72 & 1.97 & 5.64 \\
\hline & & 23.08 & 19.38 & 16.55 & 15.35 & 27.63 & 23.51 \\
\hline & & 23.08 & 23.35 & 35.86 & 29.15 & 24.34 & 30.09 \\
\hline & & 42.31 & 29.52 & 30.34 & 33.64 & 31.58 & 24.76 \\
\hline & & 11.54 & 22.47 & 13.79 & 18.14 & 14.47 & 15.99 \\
\hline & & $(26)$ & $(227)$ & $(145)$ & $(645)$ & $(152)$ & $(319)$ \\
\hline \multirow{6}{*}{$\begin{array}{l}\text { Having well } \\
\text { educated parents } \\
\chi^{2}=30.2 \\
\text { prob. }=0.07\end{array}$} & Essential & 7.69 & 8.33 & 6.76 & 5.25 & 5.13 & 9.17 \\
\hline & Very important & 42.31 & 32.02 & 29.73 & 33.49 & 40.38 & 40.67 \\
\hline & Fairly important & 30.77 & 36.84 & 43.24 & 39.97 & 39.74 & 35.17 \\
\hline & Not very important & 7.69 & 14.91 & 14.86 & 16.51 & 11.54 & 11.01 \\
\hline & Not important at all & 11.54 & 7.89 & 5.41 & 4.78 & 3.21 & 3.98 \\
\hline & & $(26)$ & (228) & $(148)$ & $(648)$ & $(156)$ & $(327)$ \\
\hline \multirow{6}{*}{$\begin{array}{l}\text { Having a good } \\
\text { education yourself } \\
\chi^{2}=16.8 \\
\text { prob. }=0.67\end{array}$} & Essential & 38.46 & 36.52 & 30.41 & 37.25 & 32.91 & 34.46 \\
\hline & Very important & 34.62 & 50.00 & 49.32 & 47.79 & 53.80 & 52.31 \\
\hline & Fairly important & 26.92 & 11.74 & 19.59 & 13.28 & 12.66 & 12.00 \\
\hline & Not very important & 0.00 & 1.74 & 0.68 & 1.53 & 0.63 & 1.23 \\
\hline & Not important at all & 0.00 & 0.00 & 0.00 & 0.15 & 0.00 & 0.00 \\
\hline & & $(26)$ & $(230)$ & (148) & $(655)$ & $(158)$ & $(325)$ \\
\hline \multirow{6}{*}{$\begin{array}{l}\text { Ambition } \\
\chi^{2}=14.4 \\
\text { prob. }=0.81\end{array}$} & Essential & 50.00 & 41.23 & 38.62 & 42.46 & 39.61 & 38.84 \\
\hline & Very important & 42.31 & 44.74 & 46.90 & 46.92 & 48.05 & 51.38 \\
\hline & Fairly important & 7.69 & 12.72 & 12.41 & 9.69 & 9.74 & 8.26 \\
\hline & Not very important & 0.00 & 0.88 & 2.07 & 0.77 & 2.60 & 1.53 \\
\hline & Not important at all & 0.00 & 0.44 & 0.00 & 0.15 & 0.00 & 0.00 \\
\hline & & $(26)$ & (228) & $(145)$ & $(650)$ & (154) & (327) \\
\hline
\end{tabular}


Table 14 continued.

\begin{tabular}{|c|c|c|c|c|c|c|c|}
\hline Response item & Response & Farmers & Nonfarm rural & Non-metropolitan & Suburban & Medium city & Large city \\
\hline $\begin{array}{l}\text { Natural ability } \\
\chi^{2}=21.4 \\
\text { prob. }=0.38\end{array}$ & $\begin{array}{l}\text { Essential } \\
\text { Very important } \\
\text { Fairly important } \\
\text { Not very important } \\
\text { Not important at all }\end{array}$ & $\begin{array}{c}11.54 \\
69.23 \\
19.23 \\
0.00 \\
0.00 \\
(26)\end{array}$ & $\begin{array}{c}15.35 \\
50.00 \\
31.14 \\
3.07 \\
0.44 \\
(228)\end{array}$ & $\begin{array}{c}6.16 \\
50.00 \\
39.04 \\
4.11 \\
0.68 \\
(146)\end{array}$ & $\begin{array}{c}14.04 \\
45.68 \\
36.27 \\
3.70 \\
0.31 \\
(648)\end{array}$ & $\begin{array}{c}14.01 \\
46.50 \\
35.03 \\
3.18 \\
1.27 \\
(157)\end{array}$ & $\begin{array}{c}15.43 \\
50.62 \\
30.25 \\
3.40 \\
0.31 \\
(324)\end{array}$ \\
\hline $\begin{array}{l}\text { Hard work } \\
\chi^{2}=32.0 \\
\text { prob. }=0.04\end{array}$ & $\begin{array}{l}\text { Essential } \\
\text { Very important } \\
\text { Fairly important } \\
\text { Not very important } \\
\text { Not important at all }\end{array}$ & $\begin{array}{c}38.46 \\
46.15 \\
15.38 \\
0.00 \\
0.00 \\
(26)\end{array}$ & $\begin{array}{c}38.10 \\
54.98 \\
6.06 \\
0.43 \\
0.43 \\
(231)\end{array}$ & $\begin{array}{c}25.50 \\
66.44 \\
6.71 \\
1.34 \\
0.00 \\
(149)\end{array}$ & $\begin{array}{c}39.57 \\
50.23 \\
8.52 \\
1.37 \\
0.30 \\
(657)\end{array}$ & $\begin{array}{c}40.88 \\
50.94 \\
6.29 \\
1.26 \\
0.63 \\
(159)\end{array}$ & $\begin{array}{c}33.54 \\
50.77 \\
13.23 \\
2.15 \\
0.31 \\
(325)\end{array}$ \\
\hline $\begin{array}{l}\text { Knowing the right } \\
\text { people } \\
\chi^{2}=46.2 \\
\text { prob. }=0.00\end{array}$ & $\begin{array}{l}\text { Essential } \\
\text { Very important } \\
\text { Fairly important } \\
\text { Not very important } \\
\text { Not important at all }\end{array}$ & $\begin{array}{c}15.38 \\
26.92 \\
34.62 \\
11.54 \\
11.54 \\
(26)\end{array}$ & $\begin{array}{c}6.96 \\
40.43 \\
37.83 \\
13.48 \\
1.30 \\
(230)\end{array}$ & $\begin{array}{c}4.05 \\
33.78 \\
50.68 \\
9.46 \\
2.03 \\
(148)\end{array}$ & $\begin{array}{c}8.72 \\
31.96 \\
46.18 \\
11.93 \\
1.22 \\
(654)\end{array}$ & $\begin{array}{c}8.86 \\
41.77 \\
39.87 \\
8.23 \\
1.27 \\
(158)\end{array}$ & $\begin{array}{c}12.38 \\
38.08 \\
36.53 \\
10.53 \\
2.48 \\
(323)\end{array}$ \\
\hline $\begin{array}{l}\text { Having political } \\
\text { connections } \\
\chi^{2}=44.5 \\
\text { prob. }=0.00\end{array}$ & $\begin{array}{l}\text { Essential } \\
\text { Very important } \\
\text { Fairly important } \\
\text { Not very important } \\
\text { Not important at all }\end{array}$ & $\begin{array}{c}4.35 \\
17.39 \\
43.48 \\
26.09 \\
8.70 \\
(23)\end{array}$ & $\begin{array}{c}4.05 \\
16.67 \\
27.48 \\
36.04 \\
15.77 \\
(222)\end{array}$ & $\begin{array}{c}1.43 \\
13.57 \\
40.71 \\
30.00 \\
14.29 \\
(140)\end{array}$ & $\begin{array}{c}2.52 \\
13.09 \\
29.50 \\
39.59 \\
15.30 \\
(634)\end{array}$ & $\begin{array}{c}6.08 \\
16.22 \\
31.08 \\
37.16 \\
9.46 \\
(148)\end{array}$ & $\begin{array}{c}5.66 \\
21.70 \\
32.70 \\
25.79 \\
14.15 \\
(318)\end{array}$ \\
\hline $\begin{array}{l}\text { A person's race } \\
\chi^{2}=29.8 \\
\text { prob. }=0.07\end{array}$ & $\begin{array}{l}\text { Essential } \\
\text { Very important } \\
\text { Fairly important } \\
\text { Not very important } \\
\text { Not important at all }\end{array}$ & $\begin{array}{c}0.00 \\
16.00 \\
28.00 \\
36.00 \\
20.00 \\
(25)\end{array}$ & $\begin{array}{c}4.02 \\
12.05 \\
24.55 \\
37.95 \\
21.43 \\
(224)\end{array}$ & $\begin{array}{c}1.39 \\
15.28 \\
27.78 \\
29.86 \\
25.69 \\
(144)\end{array}$ & $\begin{array}{c}2.21 \\
13.09 \\
25.08 \\
36.28 \\
23.34 \\
(634)\end{array}$ & $\begin{array}{c}2.61 \\
20.92 \\
25.49 \\
22.88 \\
28.10 \\
(153)\end{array}$ & $\begin{array}{c}3.77 \\
19.50 \\
19.81 \\
32.39 \\
24.53 \\
(318)\end{array}$ \\
\hline
\end{tabular}


Table 14 continued.

\begin{tabular}{|c|c|c|c|c|c|c|c|}
\hline Response item & Response & Farmers & Nonfarm rural & Non-metropolitan & Suburban & Medium city & Large city \\
\hline $\begin{array}{l}\text { A person's religion } \\
\chi^{2}=43.5 \\
\text { prob. }=0.00\end{array}$ & $\begin{array}{l}\text { Essential } \\
\text { Very important } \\
\text { Fairly important } \\
\text { Not very important } \\
\text { Not important at all }\end{array}$ & $\begin{array}{c}8.00 \\
20.00 \\
20.00 \\
28.00 \\
24.00 \\
(25)\end{array}$ & $\begin{array}{l}4.87 \\
17.26 \\
18.14 \\
30.09 \\
29.65 \\
(226)\end{array}$ & $\begin{array}{l}2.76 \\
13.79 \\
13.10 \\
36.55 \\
33.79 \\
(145)\end{array}$ & $\begin{array}{l}4.37 \\
10.14 \\
12.17 \\
36.35 \\
36.97 \\
(641)\end{array}$ & $\begin{array}{c}6.54 \\
21.57 \\
15.03 \\
26.80 \\
30.07 \\
(153)\end{array}$ & $\begin{array}{c}5.97 \\
8.49 \\
18.24 \\
32.70 \\
34.59 \\
(318)\end{array}$ \\
\hline $\begin{array}{l}\text { The part of the } \\
\text { country a person } \\
\text { comes from } \\
\chi^{2}=27.1 \\
\text { prob. }=0.13\end{array}$ & $\begin{array}{l}\text { Essential } \\
\text { Very important } \\
\text { Fairly important } \\
\text { Not very important } \\
\text { Not important at all }\end{array}$ & $\begin{array}{c}8.70 \\
0.00 \\
8.70 \\
47.83 \\
34.75 \\
(23)\end{array}$ & $\begin{array}{c}2.65 \\
10.62 \\
17.26 \\
35.84 \\
33.63 \\
(226)\end{array}$ & $\begin{array}{c}0.68 \\
8.78 \\
14.86 \\
39.86 \\
35.81 \\
(148)\end{array}$ & $\begin{array}{l}1.71 \\
4.98 \\
17.60 \\
37.54 \\
38.16 \\
(642)\end{array}$ & $\begin{array}{c}2.65 \\
7.95 \\
10.60 \\
38.41 \\
40.40 \\
(151)\end{array}$ & $\begin{array}{c}1.88 \\
7.19 \\
13.44 \\
39.06 \\
38.44 \\
(320)\end{array}$ \\
\hline $\begin{array}{l}\text { Being born a man } \\
\text { or a woman } \\
\chi^{2}=33.5 \\
\text { prob. }=0.03\end{array}$ & $\begin{array}{l}\text { Essential } \\
\text { Very important } \\
\text { Fairly important } \\
\text { Not very important } \\
\text { Not important at all }\end{array}$ & $\begin{array}{c}4.00 \\
8.00 \\
12.00 \\
44.00 \\
32.00 \\
(25)\end{array}$ & $\begin{array}{c}3.21 \\
14.22 \\
19.27 \\
30.73 \\
32.57 \\
(218)\end{array}$ & $\begin{array}{c}1.36 \\
9.52 \\
26.53 \\
34.69 \\
27.89 \\
(147)\end{array}$ & $\begin{array}{l}3.42 \\
11.98 \\
23.64 \\
34.68 \\
26.28 \\
(643)\end{array}$ & $\begin{array}{c}6.12 \\
8.84 \\
23.13 \\
29.25 \\
32.65 \\
(147)\end{array}$ & $\begin{array}{l}2.87 \\
20.06 \\
22.93 \\
28.66 \\
25.48 \\
(314)\end{array}$ \\
\hline $\begin{array}{l}\text { A person's political } \\
\text { beliefs } \\
\chi^{2}=18.7 \\
\text { prob. }=0.54\end{array}$ & $\begin{array}{l}\text { Essential } \\
\text { Very important } \\
\text { Fairly important } \\
\text { Not very important } \\
\text { Not important at all }\end{array}$ & $\begin{array}{c}4.17 \\
4.17 \\
25.00 \\
45.83 \\
20.83 \\
(24)\end{array}$ & $\begin{array}{c}3.18 \\
10.45 \\
27.27 \\
34.09 \\
25.00 \\
(220)\end{array}$ & $\begin{array}{c}0.69 \\
9.03 \\
25.69 \\
33.33 \\
31.25 \\
(144)\end{array}$ & $\begin{array}{l}1.57 \\
7.70 \\
24.21 \\
38.84 \\
27.67 \\
(636)\end{array}$ & $\begin{array}{c}3.36 \\
10.07 \\
28.86 \\
34.90 \\
22.82 \\
(149)\end{array}$ & $\begin{array}{l}2.24 \\
10.86 \\
28.12 \\
37.38 \\
21.41 \\
(313)\end{array}$ \\
\hline
\end{tabular}


The $\chi^{2}$ s for farmers versus nonfarmers are as follows:

Coming from a wealthy family

Having well educated parents

$\chi^{2} \quad$ prob.

Having a good education yourself

$\begin{array}{ll}.2 & 0.52 \\ 3.8 & 0.43\end{array}$

Ambition

Natural ability

Hard work

Knowing the right people

Having political connections

A person's race

A person's religion

$3.8 \quad 0.43$

$\begin{array}{ll}.8 & 0.43 \\ 1 & 0.28\end{array}$

20.88

5.20 .26

1.90 .75

$\begin{array}{ll}6.6 & 0.00\end{array}$

$2.2 \quad 0.70$

$\begin{array}{lll}1.1 & 0.90 \\ 3.1 & 0.54\end{array}$

The part of the country a person comes from $\quad 8.2 \quad 0.08$

Being born a man or a woman $\quad 3.1 \quad 0.54$

$\begin{array}{lll}\text { A person's political beliefs } & 1.9 & 0.75\end{array}$

Table 15. Some people say that people get ahead by their own hard work; others say that lucky breaks or help from other people are more important. Which do you think is most important?

\begin{tabular}{|c|c|c|c|c|c|c|}
\hline Response & Farmers & Nonfarm rural & Non-metropolitan & Suburban & Medium city & Large city \\
\hline \multirow{5}{*}{$\begin{array}{l}\text { Hard work most important } \\
\text { Hard work, luck equally important } \\
\text { Luck most important }\end{array}$} & \multicolumn{6}{|c|}{$\begin{array}{c}\text { percent } \\
\text { (total number responding) }\end{array}$} \\
\hline & 61.28 & 68.01 & 65.45 & 64.15 & 63.28 & 60.85 \\
\hline & 24.81 & 21.88 & 23.57 & 23.16 & 23.47 & 24.20 \\
\hline & 13.91 & 10.12 & 10.98 & 12.69 & 13.25 & 14.95 \\
\hline & $(266)$ & $(2,985)$ & $(2,240)$ & $(7,526)$ & $(1,939)$ & $(3,451)$ \\
\hline$\chi^{2}=53.7$, prob. $=0.00$ & & & & & & \\
\hline
\end{tabular}

For farmers versus nonfarmers, $\chi^{2}=1.0$, prob. $=0.60$. 


\section{Outlook on Life}

Table 16. Anomia scale.

\begin{tabular}{|c|c|c|c|c|c|c|c|}
\hline Response item & Response & Farmers & Nonfarm rural & Non-metropolitan & Suburban & Medium city & Large city \\
\hline \multirow[b]{2}{*}{$\begin{array}{l}\text { Next to health, money is the most } \\
\text { important thing in life. } \\
\chi^{2}=20.5 \text {, prob. }=0.00\end{array}$} & \multirow[b]{2}{*}{$\begin{array}{c}\text { agree } \\
\text { disagree }\end{array}$} & \multicolumn{6}{|c|}{$\begin{array}{c}\text { percent } \\
\text { (total number responding) }\end{array}$} \\
\hline & & $\begin{array}{l}29.76 \\
70.24 \\
(84)\end{array}$ & $\begin{array}{l}27.75 \\
72.25 \\
(728)\end{array}$ & $\begin{array}{l}34.69 \\
65.31 \\
(614)\end{array}$ & $\begin{array}{c}30.19 \\
69.81 \\
(1,663)\end{array}$ & $\begin{array}{l}31.44 \\
68.56 \\
(458)\end{array}$ & $\begin{array}{l}36.79 \\
63.21 \\
(916)\end{array}$ \\
\hline $\begin{array}{l}\text { You sometimes can't help wondering } \\
\text { whether anything is worthwhile } \\
\text { anymore. } \\
\chi^{2}=21.9, \text { prob. }=0.00\end{array}$ & $\begin{array}{c}\text { agree } \\
\text { disagree }\end{array}$ & $\begin{array}{l}36.90 \\
63.10 \\
(84)\end{array}$ & $\begin{array}{l}46.19 \\
53.81 \\
(721)\end{array}$ & $\begin{array}{l}41.24 \\
58.76 \\
(611)\end{array}$ & $\begin{array}{c}38.20 \\
61.80 \\
(1,657)\end{array}$ & $\begin{array}{l}39.21 \\
60.79 \\
(454)\end{array}$ & $\begin{array}{l}45.59 \\
54.41 \\
(908)\end{array}$ \\
\hline $\begin{array}{l}\text { To make money, there are no right } \\
\text { and wrong ways any more, only easy } \\
\text { and hard ways. } \\
\chi^{2}=11.1 \text {, prob. }=0.05\end{array}$ & $\begin{array}{c}\text { agree } \\
\text { disagree }\end{array}$ & $\begin{array}{l}26.51 \\
73.49 \\
(83)\end{array}$ & $\begin{array}{l}25.18 \\
74.82 \\
(707)\end{array}$ & $\begin{array}{l}27.39 \\
72.61 \\
(606)\end{array}$ & $\begin{array}{c}22.02 \\
77.98 \\
(1,630)\end{array}$ & $\begin{array}{l}26.52 \\
73.48 \\
(445)\end{array}$ & $\begin{array}{l}26.41 \\
73.59 \\
(905)\end{array}$ \\
\hline $\begin{array}{l}\text { Nowadays, a person has to live } \\
\text { pretty much for today and let } \\
\text { tomorrow take care of itself. } \\
\chi^{2}=25.0, \text { prob. }=0.00\end{array}$ & $\begin{array}{c}\text { agree } \\
\text { disagree }\end{array}$ & $\begin{array}{l}39.29 \\
60.71 \\
(84)\end{array}$ & $\begin{array}{l}49.38 \\
50.57 \\
(725)\end{array}$ & $\begin{array}{l}49.43 \\
50.57 \\
(613)\end{array}$ & $\begin{array}{c}40.49 \\
59.41 \\
(1,658)\end{array}$ & $\begin{array}{l}45.18 \\
54.82 \\
(456)\end{array}$ & $\begin{array}{l}46.12 \\
53.88 \\
(915)\end{array}$ \\
\hline $\begin{array}{l}\text { In spite of what some people say, } \\
\text { the lot of the average man is getting } \\
\text { worse, not better. } \\
\chi^{2}=85.1 \text {, prob. }=0.00\end{array}$ & $\begin{array}{c}\text { agree } \\
\text { disagree }\end{array}$ & $\begin{array}{l}58.91 \\
41.09 \\
(258)\end{array}$ & $\begin{array}{c}65.44 \\
34.56 \\
(2,911)\end{array}$ & $\begin{array}{c}60.77 \\
39.23 \\
(2,182)\end{array}$ & $\begin{array}{c}57.39 \\
42.61 \\
(7,338)\end{array}$ & $\begin{array}{c}60.38 \\
39.62 \\
(1,893)\end{array}$ & $\begin{array}{c}64.78 \\
35.22 \\
(3,367)\end{array}$ \\
\hline $\begin{array}{l}\text { It's hardly fair to bring a child into } \\
\text { the world with the way things look } \\
\text { for the future. } \\
\chi^{2}=105.5, \text { prob. }=0.00\end{array}$ & $\begin{array}{l}\text { agree } \\
\text { disagree }\end{array}$ & $\begin{array}{l}40.54 \\
59.46 \\
(259)\end{array}$ & $\begin{array}{c}45.49 \\
54.51 \\
(2,928)\end{array}$ & $\begin{array}{c}41.73 \\
58.27 \\
(2,207)\end{array}$ & $\begin{array}{c}35.34 \\
64.66 \\
(7,383)\end{array}$ & $\begin{array}{c}39.93 \\
60.07 \\
(1,901)\end{array}$ & $\begin{array}{c}40.98 \\
59.02 \\
(3,377)\end{array}$ \\
\hline
\end{tabular}


Table 16 continued.

\begin{tabular}{|c|c|c|c|c|c|c|c|}
\hline Response item & Response & Farmers & Nonfarm rural & Non-metropolitan & Suburban & Medium city & Large city \\
\hline \multirow{4}{*}{$\begin{array}{l}\text { Most public officials are not really } \\
\text { interested in the problems of the } \\
\text { average man. } \\
\chi^{2}=53.8 \text {, prob. }=0.00\end{array}$} & agree & 67.94 & 72.40 & 66.44 & 65.90 & 65.90 & 70.10 \\
\hline & disagree & 32.06 & 27.60 & 33.56 & 34.10 & 34.10 & 29.90 \\
\hline & & $(262)$ & $(2,924)$ & $(2,190)$ & $(7,363)$ & $(1,906)$ & $(3,378)$ \\
\hline & & & & & & & \\
\hline \multirow{3}{*}{$\begin{array}{l}\text { These days a person doesn't really } \\
\text { know whom he can count on. } \\
\chi^{2}=20.8, \text { prob. }=0.00\end{array}$} & agree & 69.41 & 77.55 & 72.91 & 69.52 & 68.64 & 73.88 \\
\hline & disagree & 30.59 & 22.45 & 27.09 & 30.48 & 31.36 & 26.12 \\
\hline & & $(85)$ & $(726)$ & $(609)$ & $(1,647)$ & $(456)$ & $(915)$ \\
\hline \multirow{3}{*}{$\begin{array}{l}\text { Most people don't really care what } \\
\text { happens to the next fellow. } \\
\chi^{2}=22.8 \text {, prob. }=0.00\end{array}$} & agree & 54.22 & 61.89 & 56.98 & 51.88 & 54.27 & 57.35 \\
\hline & disagree & 45.78 & 38.11 & 43.02 & 48.12 & 45.76 & 42.65 \\
\hline & & $(83)$ & (719) & $(609)$ & $(1,652)$ & $(457)$ & $(905)$ \\
\hline
\end{tabular}

The $\chi^{2}$ s for farmers versus nonfarmers are as follows:

Next to health, money is the most important thing in life.

You sometimes can't help wondering whether anything is worthwhile anymore.

$\chi^{2} \quad$ prob

To make money, there are no right and wrong ways any more, only easy and hard ways.

Nowadays, a person has to live pretty much for today and let tomorrow take care of itself.

In spite of what some people say, the lot of the average man is getting worse, not better.

It's hardly fair to bring a child into the world with the way things look for the future.

Most public officials are not really interest in the problems of the average man.

These days a person doesn't really know whom he can count on.

Most people don't really care what happens to the next fellow.

$\begin{array}{ll}0.2 & 0.67 \\ 0.7 & 0.39 \\ 0.2 & 0.70 \\ 1.1 & 0.30 \\ 0.4 & 0.53 \\ 0.2 & 0.70 \\ 0.0 & 0.97 \\ 0.3 & 0.58 \\ 0.1 & 0.80\end{array}$


Table 17. Taken all together, how would you say things are these days - would you say that you are very happy, pretty happy, or not too happy?

\begin{tabular}{|c|c|c|c|c|c|c|}
\hline Response & Farmers & Nonfarm rural & Non-metropolitan & Suburban & Medium city & Large city \\
\hline \multirow{6}{*}{$\begin{array}{l}\text { Very happy } \\
\text { Pretty happy } \\
\text { Not too happy } \\
\chi^{2}=190.3 \text {, prob. }=0.00\end{array}$} & \multicolumn{6}{|c|}{$\begin{array}{c}\text { percent } \\
\text { (total number responding) }\end{array}$} \\
\hline & 34.76 & 36.11 & 33.32 & 34.29 & 31.42 & 27.02 \\
\hline & 54.05 & 53.22 & 55.58 & 54.73 & 55.50 & 56.59 \\
\hline & 11.19 & 10.67 & 11.10 & 10.98 & 13.08 & 16.39 \\
\hline & $(420)$ & $(4,602)$ & $(3,505)$ & $(11,599)$ & $(2,944)$ & $(5,303)$ \\
\hline & & & & & & \\
\hline
\end{tabular}

For farmers versus nonfarmers, $\chi^{2}=0.9$, prob. $=0.64$. 
Table 18. Regression results of nonfarmer-farmer differences.

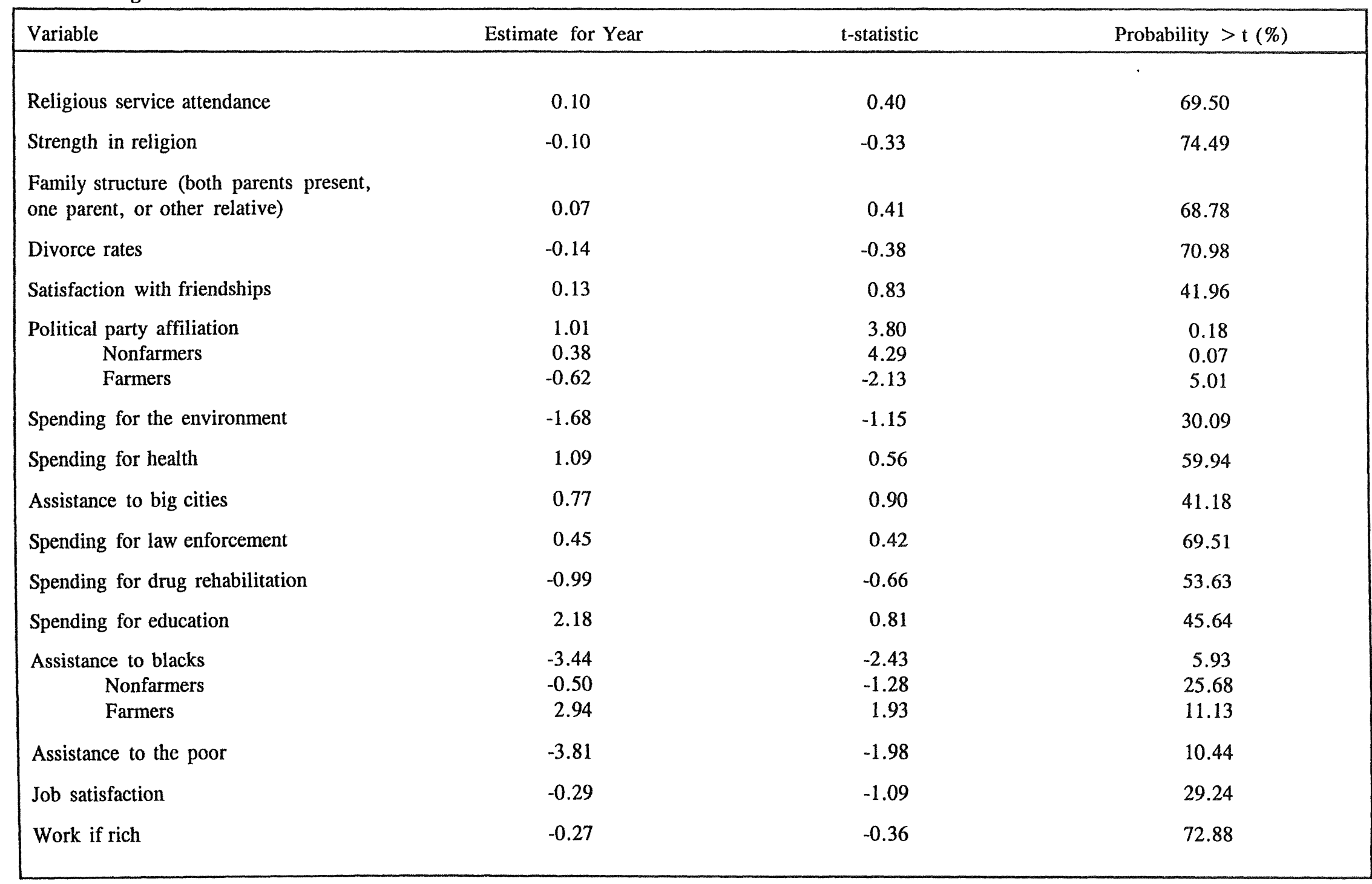


